\title{
Evidence for a Low Affinity but High Velocity Aspartate Transport System Needed for Rapid Growth of Bacillus subtilis on Aspartate as Sole Carbon Source
}

\author{
By PATRICIA A. WHITEMAN, TADAKO IIJIMA, \\ MARTIN D. DIESTERHAFT* AND ERNST FREESE \\ Laboratory of Molecular Biology, National Institute of Neurological and Communicative \\ Disorders and Stroke, National Institutes of Health, Bethesda, Maryland 20014, U.S.A. \\ *General Medical Research, Veterans Administration Hospital, \\ Iowa City, Iowa 52240, U.S.A.
}

(Received 2 February 1978)

\begin{abstract}
Mutants (aspT) of Bacillus subtilis which lack the high affinity transport of L-aspartate and L-glutamate have been isolated by their resistance to DL-threo- $\beta$-hydroxyaspartate. They transport low concentrations $(100 \mu \mathrm{M})$ of all three amino acids at a greatly reduced rate but they can still grow at the normal rate on high concentrations of aspartate $(25 \mathrm{mM})$ as sole carbon source. The aspT mutation has been mapped between $\arg C$ and $g l p K, g l p D$. In glucose/citrate medium, an $a s p B$ mutant, auxotrophic for aspartate, requires much lower aspartate concentrations for growth than an aspB asp $T$ double mutant. These results demonstrate that a low affinity aspartate transport system is still present in aspT mutant strains. This was also shown by the fact that both aspH and aspH aspT mutants, which carry the gene (aspH) for high aspartase production, grew at the same rate in media containing high concentrations $(25 \mathrm{~mm})$ of L-aspartate as sole carbon source. The high affinity aspartate transport system $\left(K_{\mathrm{m}}=67 \mu \mathrm{M}\right)$ alone can satisfy the growth requirements of aspartate auxotrophs in media containing glucose or some other carbon source. However, the maximum rate $\left(V_{\max }\right)$ of this transport system is too low to allow rapid growth on aspartate as sole carbon source. For such rapid uptake the low affinity aspartate transport system is needed. Membrane vesicles, energized by glycerophosphate, exhibit only the active high affinity transport which is saturated at about $100 \mu \mathrm{M}$-L-aspartate $\left(K_{\mathrm{m}}=66 \mu \mathrm{M}\right)$. Apparently, the proton motive force, which energizes the high affinity aspartate (and glutamate) transport, is not (directly) required for the low affinity aspartate transport.
\end{abstract}

\section{INTRODUCTION}

Intact cells of Bacillus subtilis can take up high concentrations of L-malate at a faster rate (Fournier et al., 1972) than can membrane vesicles (Bisschop et al., 1975). Results of a study on the inhibitory effect of lipophilic acids (which destroy the proton motive force) have indicated that $B$. subtilis has two malate transport systems, a high affinity system energized by the proton motive force and a low affinity system which does not depend on this force and which is used for growth at high malate concentrations (Levin \& Freese, 1977). We have similarly observed that the rate of L-aspartate uptake increases rapidly with the aspartate concentration up to about $100 \mu \mathrm{M}$-aspartate and then continues to increase at a lower rate up to very high aspartate concentrations. For example, when the bacteria are grown in 25 mM-sodium aspartate, the rate of continuous aspartate uptake is more than four times higher than the maximum rate of uptake observed at $100 \mu \mathrm{M}$-aspartate. This indicates that 
Table 1. Bacillus subtilis strains used in genetic analysis

\begin{tabular}{ll} 
Strain & \multicolumn{1}{c}{ Genotype } \\
60002 & trpC2 \\
60021 & amy trpC2 \\
60348 & amy trpC2 aspT1 \\
& \\
61236 & trpC2 argC2 \\
61459 & aspB66 trpC2 \\
61501 & aspH1 trpC2
\end{tabular}

$61504 \quad \operatorname{trp} C 2 \operatorname{met} A \operatorname{argC2}$

$61505 \quad \operatorname{trpC2}$ argC2 $\mathrm{glpD}$

$61506 \quad \operatorname{trpC2}$ argC2 glpK

$61507 \quad$ aspH1 aspT13 trpC2

$61565 \quad \operatorname{trpC2}$ argC2 aspB66

$61566 \quad \operatorname{trpC2}$ aspB66 aspT1

\author{
J. Spizizen (168) \\ J. Spizizen, amylase-deficient mutant of 168 \\ strain \\ Spontaneous mutant of 60021 resistant to \\ threo-hydroxyaspartate (THA) \\ B. Reilly (BR85) \\ J. Hoch (C66) (Hoch \& Mathews, 1972) \\ Spontaneous mutant of 60002 isolated for rapid \\ growth on aspartate \\ Tf. of 61531 by $60136 \dagger$ \\ Tf. of 61531 by 61402 (Oh et al., 1973) \\ Tf. of 61531 by $61154 \dagger$ \\ Spontaneous mutant of 61501 resistant to THA \\ Tf. of 61504 by 61459 \\ Td. of 61565 by 60348
}

* Tf. implies transformation (by congression) of the first strain by DNA of the second strain; Td. implies transduction of the first strain by PBS1 phage isolated from the second strain.

$\dagger$ The met $A$ and $g l p K$ mutations have been isolated in this laboratory; they have not been mapped.

the high affinity active transport system is not sufficient to allow the rapid growth on aspartate as sole carbon source. This paper shows that $B$. subtilis has two transport systems: a high affinity system which is also found in membrane vesicles under the usual energization conditions, and a low affinity system (with a high $V_{\max }$ ) which predominates at high aspartate concentrations and which is not observed in membrane vesicles. The high affinity system is missing in mutants (aspT) which can still grow on aspartate as sole carbon source.

\section{METHODS}

Bacteria. All strains were derived from the transformable strain $168(=60002)$ of $B$. subtilis Marburg. The strains used are listed in Table 1.

Media and growth conditions. The synthetic salts mixture (S6) contained: $10 \mathrm{~mm}-\left(\mathrm{NH}_{4}\right)_{2} \mathrm{SO}_{4}, 5 \mathrm{~mm}-$ $\mathrm{K}_{2} \mathrm{HPO}_{4} / \mathrm{KH}_{2} \mathrm{PO}_{4}, \mathrm{pH} 7 \cdot 0,100 \mathrm{mM}-2$-( $N$-morpholino)propanesulphonic acid (MOPS) adjusted to pH 7.0 with $\mathrm{KOH}, 1 \mathrm{mM}-\mathrm{MgCl}_{2}, 0 \cdot 7 \mathrm{mM}-\mathrm{CaCl}_{2}, 50 \mu \mathrm{M}-\mathrm{MnCl}_{2}, 5 \mu \mathrm{M}-\mathrm{ZnCl}_{2}, 5 \mu \mathrm{M}-\mathrm{FeCl}_{3}$ and $25 \mu \mathrm{g} \mathrm{L}$-tryptophan $\mathrm{ml}^{-1}$. $\mathrm{S} 6+\mathrm{Na}^{+}$is $\mathrm{S} 6$ plus $10 \mathrm{~mm}-\mathrm{NaCl}$. Carbon sources were usually added at $25 \mathrm{~mm}$ and the dicarboxylic amino acids were adjusted to $\mathrm{pH} 7.0$ with $\mathrm{KOH}$ (or $\mathrm{NaOH}$ where stated). Plates of synthetic media were prepared by adding the growth supplements and carbon sources to a sterile warm solution of agar (Difco) so that the final agar concentration was $1.5 \%(\mathrm{w} / \mathrm{v})$.

Bacteria which had been grown overnight on plates containing tryptose blood agar base (TBAB; $33 \mathrm{~g} \mathrm{l}^{\mathbf{- 1}}$; Difco) were used to inoculate plates of synthetic medium. After incubation at $37^{\circ} \mathrm{C}$ for 15 to $20 \mathrm{~h}$, the growth was washed off and used to inoculate liquid medium to give an initial absorbance at $600 \mathrm{~nm}$ of 0.05 . The cultures were incubated at $37^{\circ} \mathrm{C}$ in a reciprocating water bath shaker and growth was followed by measuring $A_{600}$ with a Gilford spectrophotometer (model 220).

The minimal glucose/citrate medium (MG) of Anagnostopoulos \& Spizizen (1961) was used for transformation and the selection of transductants. PBS1 phage was multiplied in antibiotic medium 3 (AM3; Difco) using various donor bacteria.

Isolation of the aspT strains. Approximately $10^{7}$ bacteria from a culture of strain 60021 (trpC2) were plated on $\mathrm{S} 6+$ glucose plates containing $100 \mu \mathrm{M}$-DL-threo- $\beta$-hydroxyaspartate (THA). The plates were incubated at $37^{\circ} \mathrm{C}$ for $72 \mathrm{~h}$ and colonies were purified first on fresh plates containing THA and then on TBAB plates. Ten independent mutants were obtained, each from a different single colony isolate of strain 60021 . The isolates retained the THA-resistant property through five serial passages on TBAB plates. The aspH aspT double mutant (61507) was isolated from the asp $H$ strain (61501) in a similar manner.

Transduction experiments. Transduction by PBS1 phage was performed according to Takahashi (1966) and Hoch et al. (1967) with the modifications described elsewhere (Iijima et al., 1977).

Transformation experiments. DNA was obtained by the method of Saito \& Miura (1963). A $2.5 \mu$ g portion of donor strain DNA was added per $\mathrm{ml}$ of recipient bacteria grown according to Anagnostopoulos \& 
Spizizen (1961). In order to examine the asp $T$ region of the chromosome, it was necessary to construct several multiply marked strains by transformation. For example, strain 61531 (trpC2 lys-3 argC2 gtaC) was isolated by double transformation (congression) of strain 61530 (trpC2 metB10 lys-3 gtaC) obtained from F. Young (his strain RUB807) with DNA of strain 61236 ( $\operatorname{trpC2} \operatorname{argC2}$ ) obtained from B. Reilly (his strain BR85); $m e t B$ was transformed out while $\arg C$ was transformed in.

Isolation of an aspB aspT double mutant. DNA of strain 61459 (trpC2 aspB66) obtained from J. Hoch (his strain c66) was added to strain 61504 ( $\operatorname{trp} C 2 \mathrm{met} A$ arg $C 2)$ produced in this laboratory, to obtain, by double transformation, a trpC2 argC2 aspB66 strain (61565); aspB conveyed an aspartate requirement (on MG) to this strain. Strain 61565 was then transduced by PBS1 phage grown on strain 60348 (trpC2 aspTI). Since the asp $T$ gene is linked to the $\arg C$ gene, many $\mathrm{Arg}^{+}$transductants contained the asp $T 1$ marker whose presence was demonstrated by growth on $\mathrm{MG}+$ tryptophan + aspartate. Whereas the asp $B$ mutant required only $300 \mu \mathrm{M}$-aspartate for good colony growth, the aspB asp $T$ double mutants required $6 \mathrm{~mm}$-aspartate. One such double mutant, the trpC2 aspB66 aspT1 strain (61566), was used in this work.

Uptake studies in whole organisms. During exponential growth in $\mathrm{S} 6$ or $\mathrm{S} 6+\mathrm{Na}^{+}$plus different carbon sources, the bacteria were harvested (at $A_{600}=0.5$ or 1.0$)$ by centrifugation $(12000 \mathrm{~g}$, room temp., $5 \mathrm{~min}$ ), washed once with an equal volume of $\mathrm{S} 6$ and resuspended in the same medium. Portions (2 to $4 \mathrm{ml})$ were transferred to 50 or $100 \mathrm{ml}$ flasks and incubated in a water bath shaker at $37^{\circ} \mathrm{C}$ for $2 \mathrm{~min}$. Chloramphenicol $\left(100 \mu \mathrm{g} \mathrm{ml}^{-1}\right)$ was included in the resuspension where indicated and, when necessary, an energy source was added just before the addition of ${ }^{14} \mathrm{C}$-labelled substrate as described in the text.

High affinity uptake was initiated by the addition of potassium $\mathrm{L}_{-}\left[\mathrm{U}_{-}{ }^{14} \mathrm{C}\right]$ aspartate $\left(1 \mu \mathrm{Ci} \mu \mathrm{mol}^{-1}\right)$, or another amino acid, to give a final concentration of 0.1 to $0.2 \mathrm{~mm}$ and a radioactivity of 100 to $200 \mathrm{nCi} \mathrm{ml}^{-1}$. Low affinity uptake was initiated by the addition of potassium $\mathrm{L}-\left[\mathrm{U}-{ }^{14} \mathrm{C}\right]$ aspartate or potassium $\mathrm{L}-\left[\mathrm{U}-{ }^{14} \mathrm{C}\right] \mathrm{glu}-$ tamate $\left(0.1 \mu \mathrm{Ci} \mu \mathrm{mol}^{-1}\right)$ to give a final concentration of 5 to $25 \mathrm{~mm}$ and a radioactivity of $1.0 \mu \mathrm{Ci} \mathrm{ml}{ }^{-1}$ or $2 \cdot 5 \mu \mathrm{Ci} \mathrm{ml}{ }^{-1}$.

DL-threo- $\beta$-Hydroxy[ $\left.3,4-{ }^{14} \mathrm{C}\right]$ aspartic acid was prepared from $\left[\mathrm{U}-{ }^{14} \mathrm{C}\right] \mathrm{glyoxylic}$ acid $\left(7 \cdot 5 \mathrm{mCi} \mathrm{mmol}^{-1}\right.$; Amersham/Searle) as described by Kornguth \& Sallach (1960). The product $\left(7.5 \mathrm{mCi} \mathrm{mmol}^{-1}\right)$ was neutralized with $\mathrm{KOH}$ to give a solution containing $28.6 \mu \mathrm{Ci} \mathrm{ml}{ }^{-1}$. [ $\left.{ }^{14} \mathrm{C}\right] \mathrm{THA}$, of activity $0.143 \mu \mathrm{Ci} \mu \mathrm{mol}^{-1}$, was added to cells in uptake medium to give a final concentration of $0.2 \mathrm{mM}$ and $28.6 \mathrm{nCi} \mathrm{m}^{-1}$, or of activity $0.038 \mu \mathrm{Ci} \mu \mathrm{mol}^{-1}$, to give $25 \mathrm{~mm}$ and $0.95 \mu \mathrm{Ci} \mathrm{ml}{ }^{-1}$.

At different times, samples $(0.2 \mathrm{ml})$ were withdrawn, filtered rapidly on a membrane filter (type GN-6, pore size $0.45 \mu \mathrm{m}$, Gelman Instrument Co., Ann Arbor, Michigan, U.S.A.), washed three times with $5 \mathrm{ml}$ S6 prewarmed to $37^{\circ} \mathrm{C}$, and the radioactivity on the filter was counted in a liquid scintillation spectrometer. The scintillation fluid contained $758 \mathrm{ml}$ toluene, $200 \mathrm{ml}$ Triton X-100 and $42 \mathrm{ml}$ Spectrafluor (Amersham/ Searle) per litre.

The initial rates of uptake ( $\mathrm{nmol} A_{600}^{-1} \mathrm{~min}^{-1}$ ) were usually determined from the linear portion of the uptake curves consisting of four points taken within $2 \mathrm{~min}$.

Preparation of membrane vesicles and transport measurements. Membrane vesicles were prepared from cultures growing exponentially in medium containing $25 \mathrm{mM}$-glycerol and $5 \mathrm{mg}$ casein hydrolysate $\mathrm{ml}^{-1}$ using the procedure of Konings et al. (1973) with the following modifications: at the time of cell harvest, $100 \mu \mathrm{g}$ chloramphenicol $\mathrm{ml}^{-1}$ was added to the culture to stop all protein (including protease) synthesis. After the nuclease treatment, the lysate was centrifuged at $15000 \mathrm{~g}$ for $45 \mathrm{~min}$ at room temperature. The pellets were combined, suspended in $0.05 \mathrm{M}$-potassium phosphate buffer, $\mathrm{pH} 6.6$, and centrifuged at $50000 \mathrm{~g}$ for $15 \mathrm{~min}$ in the cold. The upper yellowish lipid-containing layer of the pellet was gently shaken away from the more compact darker layer of debris. The lipid layer was suspended and the process of separation repeated two to three times until only a single layer remained in the pellet. The final pellet was suspended in $0.05 \mathrm{M}$-potassium phosphate buffer, $\mathrm{pH} 6 \cdot 6$, at a protein concentration of 8 to $10 \mathrm{mg} \mathrm{ml}^{-1}$ and stored in several vials at $-70^{\circ} \mathrm{C}$. For the energization of transport, $20 \mathrm{~mm}$-dipotassium DL- $\alpha$-glycerophosphate or Tris/glycerophosphate buffer was used. These were prepared from the disodium salt by exchange on a Dowex 50 column. The concentration of the glycerophosphate was determined by glycerol-3-phosphate dehydrogenase $\left(\mathrm{NAD}^{+}\right.$) (Michal \& Lang, 1974) and the sodium content was measured by flame photometry. Transport was measured according to Kaback (1971).

\section{RESULTS AND DISCUSSION}

\section{Isolation of aspT mutants deficient in high affinity aspartate and glutamate transport}

L-Aspartate and L-glutamate are actively transported into membrane vesicles of normal strains of $B$. subtilis 168 (Konings \& Freese, 1972). In order to examine the effect of this high affinity system on growth with aspartate as sole carbon source, we isolated mutants (aspT) resistant to DL-threo- $\beta$-hydroxyaspartate (THA) as described in Methods. Figure 1 

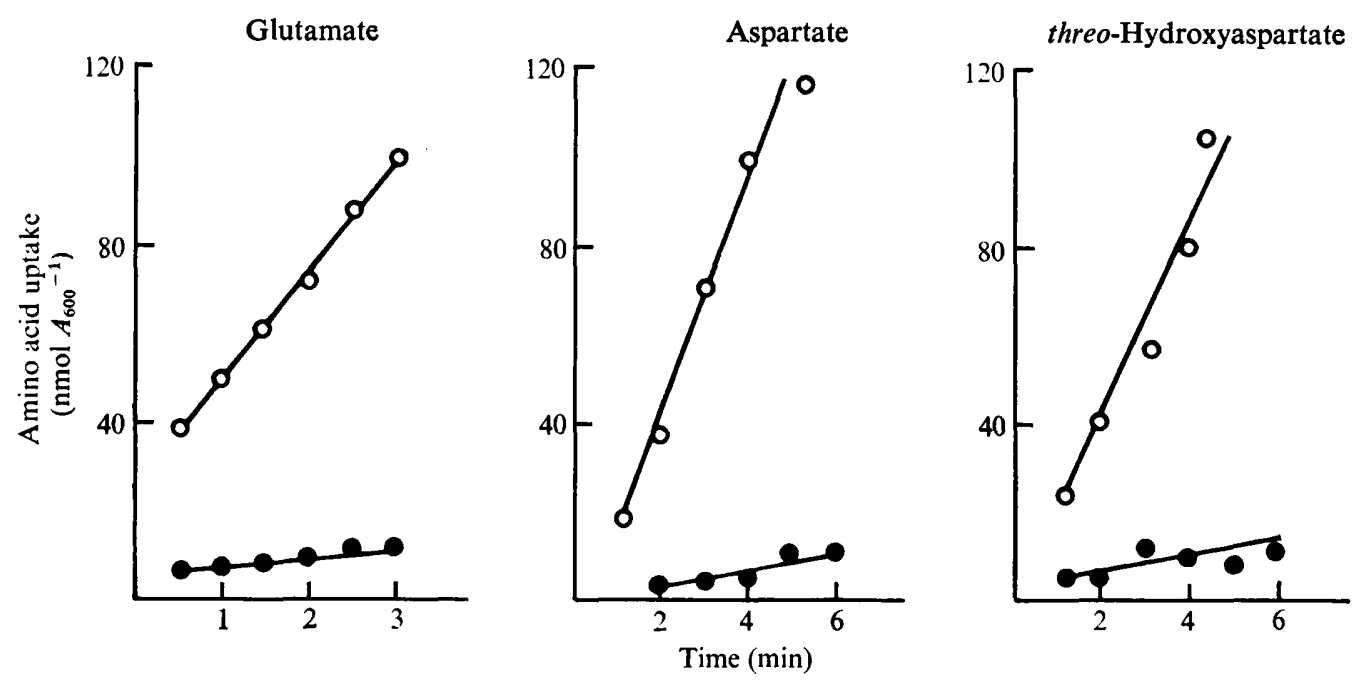

Fig. 1. Amino acid uptake by whole organisms. The standard strain $60002(0)$ and the aspT mutant 60348 (O) were grown in $\mathrm{S} 6+$ glucose to $A_{600}=1 \cdot 0$, and uptake was measured with 15 mM-glucose as energy source as described in Methods.
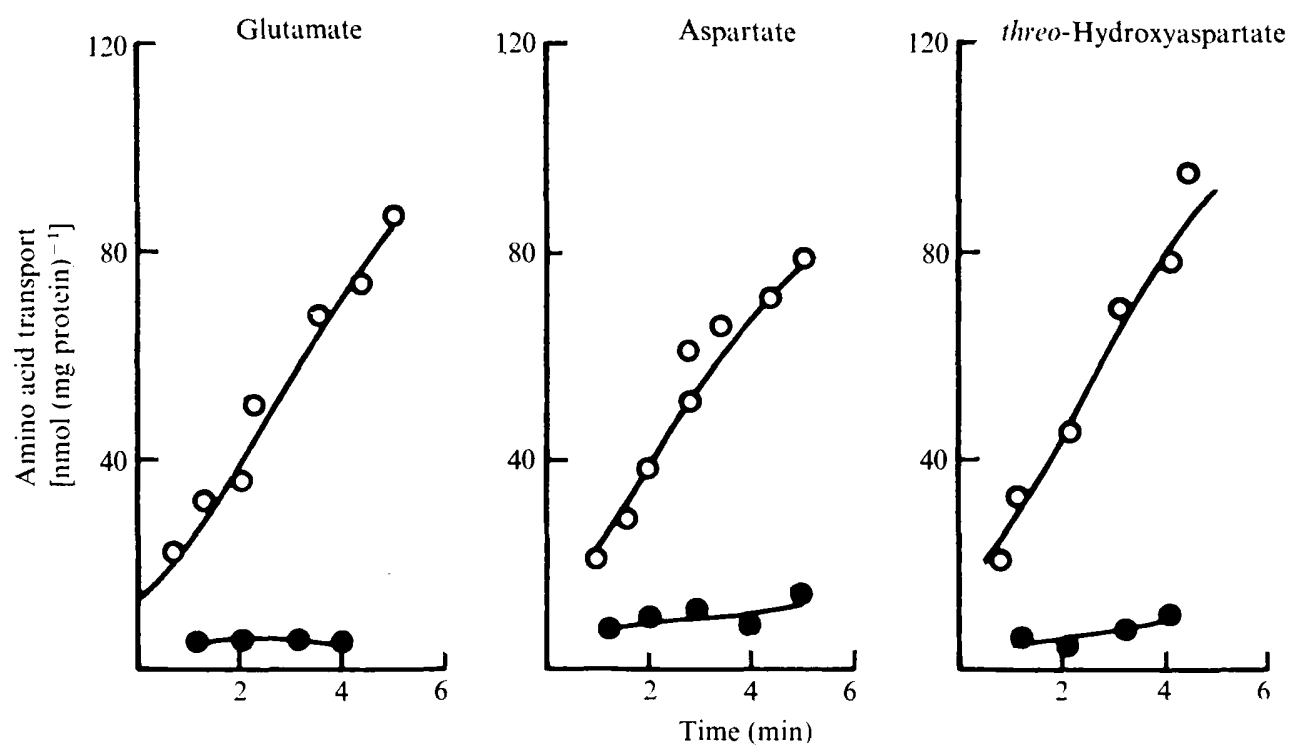

Fig. 2. Amino acid uptake by membrane vesicles. The standard strain $60002(\bigcirc)$ and the $a s p T$ mutant $60348(O)$ were grown to $A_{600}=1 \cdot 0$, vesicles were prepared and uptake was measured in the presence of $20 \mathrm{~mm}$-Tris/glycerophosphate as energy source as described in Methods.

demonstrates that intact bacteria of one of these mutants $(a s p T 1,60348)$ were deficient in the high affinity transport of aspartate (at $100 \mu \mathrm{M}$ ), as well as that of glutamate (at $500 \mu \mathrm{M}$ ) and THA (at $200 \mu \mathrm{M}$ ). The same transport deficiency was observed in membrane vesicles energized by glycerophosphate (Fig. 2). The results demonstrate that L-aspartate, Lglutamate and THA are transported in $B$. subtilis by the same 'high affinity' transport system which is apparently energized by the proton motive force (generated in this case by glycero- 


\section{Table 2. Linkage of aspT to argC and met $A$}

The donor strain was $60348(\operatorname{trp} C 2$ aspTl).

\begin{tabular}{|c|c|}
\hline \multicolumn{2}{|c|}{ PBS1 recipient } \\
\hline Strain & Genotype \\
\hline $\begin{array}{l}61236 \\
61504\end{array}$ & $\begin{array}{l}\operatorname{trp} C 2 \text { arg } C 2 \\
\operatorname{trp} C 2 \text { met } A \text { arg } C\end{array}$ \\
\hline
\end{tabular}

$\begin{array}{ccccc}\begin{array}{c}\text { Selected } \\ \text { marker }\end{array} & \begin{array}{c}\text { Sensitive } \\ \text { to THA }\end{array} & \begin{array}{c}\text { Resistant } \\ \text { to THA }\end{array} & \begin{array}{c}\text { Totected aspT } \\ \text { mamber } \\ \text { tested }\end{array} & \begin{array}{c}\text { Recombination } \\ \text { frequency }(\%)\end{array} \\ \begin{array}{r}\text { arg } \\ \text { met }\end{array} & 214 & 120 & 334 & 64 \\ & 184 & 46 & 230 & 80\end{array}$

Other recipient strains, in which 110 to 140 transductants of each of the following markers were selected, showed no cotransduction with $\operatorname{asp} T$ (resistance to THA): his $A, t h r, l e u, l y s, \operatorname{cit} B, p y r A, p u r B$.

Table 3. Three-factor crosses for aspT

The donor strain was 60348 (trpC2 aspT1).

${ }_{\arg C}^{\text {Combinations of genotypes* }} \underbrace{}_{\text {asp } T}$

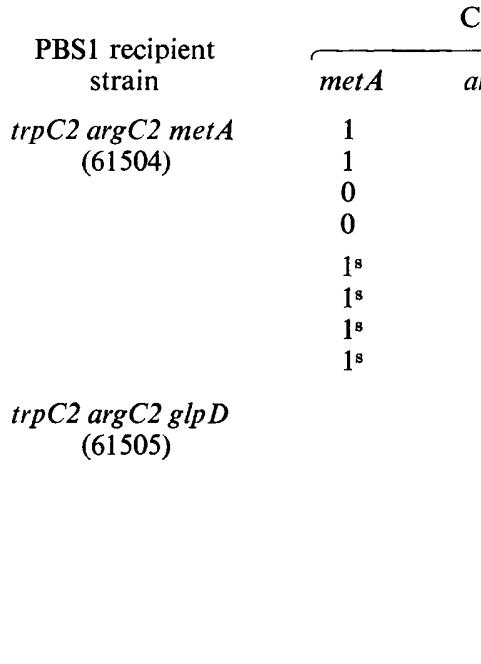

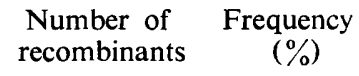

$\begin{array}{ll}1^{\mathrm{s}} & 1 \\ 1^{\mathrm{s}} & 0 \\ 1^{\mathrm{B}} & 1 \\ 1^{\mathrm{s}} & 0 \\ 1 & 1 \\ 1 & 0 \\ 0 & 1 \\ 0 & 0\end{array}$

$1^{8} \quad 1$

$\begin{array}{ll}1^{8} & 1 \\ 18 & 1\end{array}$

$\begin{array}{ll}18 & 0 \\ 1^{8} & 0\end{array}$

$1 \quad 1$

$0 \quad 1$

$\begin{array}{ll}1 & 0 \\ 0 & 0\end{array}$

$\operatorname{trpC2} \operatorname{argC2} \mathrm{glpK}$

(61506)

$\begin{array}{ll}1^{\mathrm{s}} & 1 \\ 1^{\mathrm{s}} & 1 \\ 1^{\mathrm{s}} & 0 \\ 1^{\mathrm{s}} & 0 \\ 1 & 1 \\ 0 & 1 \\ 1 & 0 \\ 0 & 0\end{array}$

$\begin{array}{ll} & \\ & \\ & \\ & \\ & \\ 1 & \\ 0 & \\ 1 & \\ 1^{\mathrm{s}} & \\ 1^{\mathrm{s}} & \\ 1^{\mathrm{s}} & \\ 1^{\mathrm{s}} & \\ & \\ & 1 \\ & 0 \\ & 1 \\ & 0 \\ & 1^{\mathrm{s}} \\ & 1^{\mathrm{s}} \\ & 1^{\mathrm{s}}\end{array}$

$\begin{array}{rr}36 & 16 \cdot 1 \\ 69 & 30 \cdot 9 \\ 76 & 34 \cdot 1 \\ 42 & 18 \cdot 8 \\ 46 & 20 \cdot 0 \\ 38 & 16 \cdot 5 \\ 0 & 0 \\ 146 & 63 \cdot 5 \\ 20 & 6 \cdot 6 \\ 138 & 45 \cdot 7 \\ 1 & 0 \cdot 3 \\ 143 & 47 \cdot 5 \\ 26 & 8 \cdot 9 \\ 78 & 26 \cdot 7 \\ 2 & 0 \cdot 7 \\ 186 & 63 \cdot 7 \\ 26 & 8 \cdot 1 \\ 161 & 50 \cdot 2 \\ 1 & 0 \cdot 3 \\ 133 & 41 \cdot 4 \\ 30 & 10 \cdot 0 \\ 82 & 27 \cdot 4 \\ 2 & 0 \cdot 7 \\ 185 & 61 \cdot 9\end{array}$

* 0 , Recipient type; 1 , donor type; $1^{\mathrm{s}}$, selected donor type (= wild type).

phosphate oxidation). Eight other aspT isolates also lacked the high affinity transport of aspartate.

\section{Mapping of the aspT mutation}

The aspT1 mutation (strain 60348) cotransduced with markers of the $\operatorname{argC}$ and met $A$ genes (Table 2). In three-factor crosses (Table 3), the order of genes was established as $m e t A \operatorname{argC} a s p T(g l p K g l p D)$. Figure 3 shows a genetic map of the $a s p T$ area, in which the marker distances (recombination frequencies) of all crosses performed are summarized. Using transduction, it was also shown that THA resistance and lack of high affinity aspartate uptake were strictly correlated. The THA resistance of eight other independent aspT mutant isolates also cotransduced with the $\arg C$ gene. 


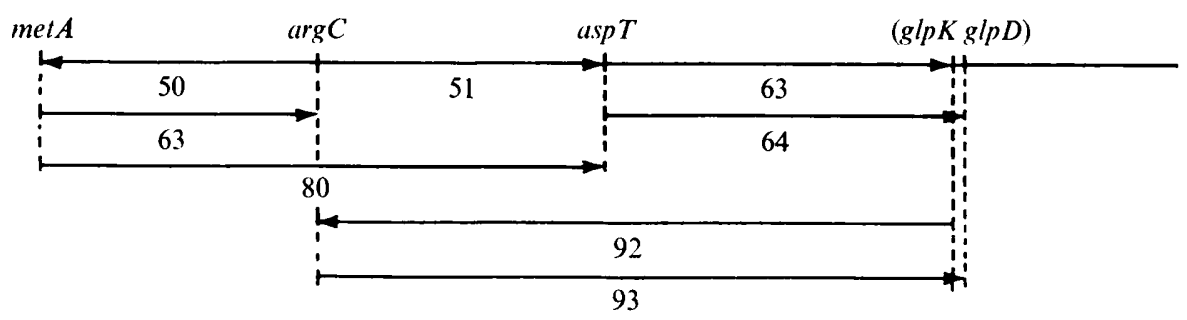

Fig. 3. Genetic map of the area surrounding aspT. The arrows are directed from the selected to the unselected marker. The numbers indicate the recombination frequencies $(\%)$.

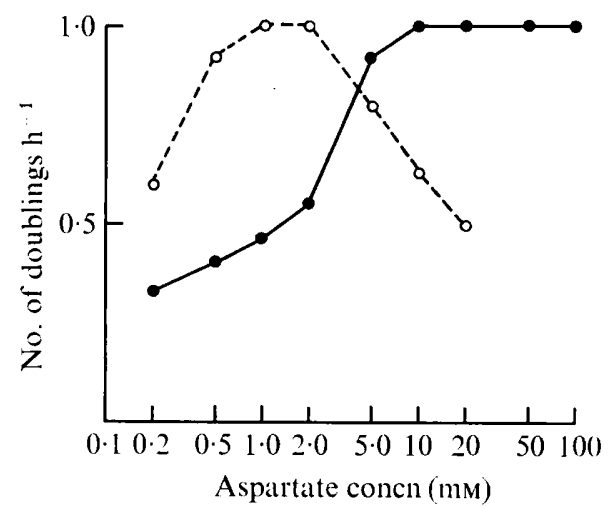

Fig. 4. Effect of the $a s p T$ mutation on growth of aspartate auxotrophs. The asp B strain $61459(O)$, lacking aspartate- $\alpha$-ketoglutarate aminotransferase activity, and the aspB aspT strain 61566 (O), lacking also the high affinity aspartate transport, were grown in $\mathrm{S} 6+25 \mathrm{~mm}$-glucose $+10 \mathrm{~mm}$ sodium citrate with different concentrations of potassium aspartate. Growth curves were plotted semilogarithmically and the linear portion was used to determine the doubling time.

\section{Evidence for a low affinity aspartate transport system}

When sodium aspartate was used as sole carbon source ( $\mathrm{S} 6+25$ mM-sodium aspartate) the aspT mutants, which lack the high affinity aspartate transport, grew at about the same rate (2.5 to $3 \mathrm{~h}$ doubling time) as the strains having the normal (high affinity) aspartate transport. Therefore, the physiological effect of the asp $T$ mutation on growth could be observed (in the absence of the inhibitor THA) only in an aspartate auxotroph. Such a mutant is the aspB strain (isolated by J. Hoch), which requires aspartate for growth in minimal glucose medium because it lacks glutamate-oxaloacetate aminotransferase activity (Hoch \& Mathews, 1972). The aspB marker was combined with the aspT1 marker in an asp $B$ aspT double mutant (61566) (see Methods). Figure 4 shows that the double mutant could grow in $\mathrm{S} 6+\mathrm{Na}^{+}+25 \mathrm{~mm}$-glucose at a reasonably high rate only if the aspartate concentration was higher than $2 \mathrm{mM}$. Apparently, the strain had to use the low affinity aspartate transport system to provide enough aspartate for protein, nucleotide and cell wall synthesis even when glucose could provide energy and other cell components. In contrast, an asp $B$ strain (61459) required much less aspartate for optimum growth. [The aspT strain (60348) naturally did not require any aspartate.] High concentrations of aspartate inhibited growth of the $a s p B$ strain (61459), possibly because aspartate (being actively transported into the cells) could not be metabolized rapidly enough since the strain did not carry the high aspartase activity resulting from the asp $H$ mutation (see below). This inhibition was not further investigated. 

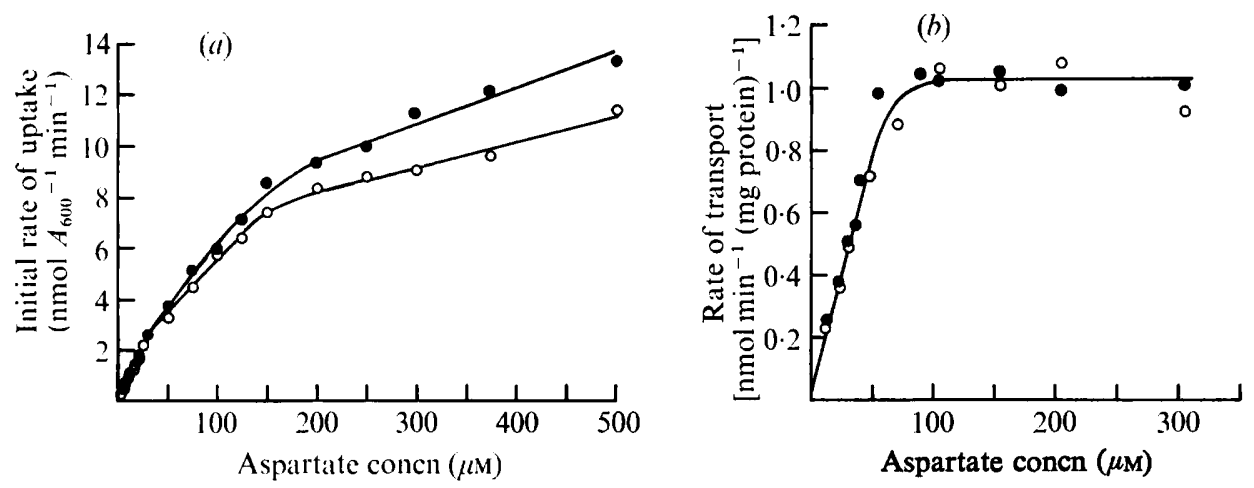

Fig. 5. Concentration dependence of aspartate uptake by $(a)$ whole organisms and $(b)$ membrane vesicles of strain $61501(\operatorname{aspH})$ in the absence $(O)$ or presence $(O)$ of $10 \mathrm{~mm}-\mathrm{NaCl}$. (a) Strain 61501 was grown in $\mathrm{S} 6+25 \mathrm{~mm}$-sodium aspartate $+25 \mathrm{~mm}$-glycerol and uptake of aspartate was measured in the presence of chloramphenicol $\left(100 \mu \mathrm{g} \mathrm{ml}^{-1}\right)$ and dipotassium glycerophosphate $(20 \mathrm{~mm})$ as energy source as described in Methods. (b) Membrane vesicles were isolated as described in Methods and uptake was measured in the presence of Tris/glycerophosphate (20 mM) as energy source.

\section{Properties of the high affinity aspartate transport system}

Normal $B$. subtilis strains grew on aspartate as sole carbon source at a low rate (doubling times 2 to $3 \mathrm{~h}$ ) even if the medium contained $\mathrm{Na}^{+}(10 \mathrm{mM})$ which distinctly increased the rate of growth on aspartate; $\mathrm{Na}^{+}$had no effect on growth in media containing glucose or malate. During other work in this laboratory (Iijima et al., 1977), a mutation (aspH) had been isolated that produced rapid growth on sodium aspartate because the strain (61501) had a high (apparently constitutive) aspartase activity. Again, growth on aspartate was greatly stimulated by the presence of $\mathrm{Na}^{+}$. To measure the relative effects of the low and the high affinity transport systems on uptake of and growth on aspartate, we have used only strains that contained the asp $H$ mutation.

During exponential growth of the aspH strain (61501) in S6 +25 mM-sodium aspartate + $25 \mathrm{~mm}$-glycerol (to induce glycerophosphate dehydrogenase, $\mathrm{NAD}^{+}$independent), bacteria were removed (at $A_{600}=0 \cdot 5$ ), washed in S6, and the uptake of L-aspartate was measured in the presence of dipotassium glycerophosphate as energy source and $10 \mathrm{~mm}-\mathrm{NaCl}$. Figure 5 (a) shows that the initial rate (within $2 \mathrm{~min}$ ) of aspartate uptake by whole organisms was almost the same with and without $\mathrm{Na}^{+}$at low aspartate concentrations $(<50 \mu \mathrm{M})$ and exhibited an $\mathrm{Na}^{+}$dependence at higher concentrations. In membrane vesicles, the aspartate uptake, energized by Tris/glycerophosphate, exhibited no $\mathrm{Na}^{+}$dependence even at high aspartate concentrations (Fig. $5 b$ ). In the absence of $\mathrm{Na}^{+}$, the apparent $K_{\mathrm{m}}$ was about $67 \mu \mathrm{M}$ for intact organisms and $66 \mu \mathrm{M}$ for membrane vesicles. When the vesicles were prepared and assayed in different buffers, such as choline $/ \mathrm{PO}_{4}$, choline/Cl, Tris/Tes [Tes, $N$-tris(hydroxymethyl)methyl-2-aminoethanesulphonic acid], Tris $/ \mathbf{P}_{1}$ or $\mathbf{K P}_{\mathbf{i}}$, different rates of aspartate transport (differences of a factor of 5) were obtained, phosphate-containing buffers giving higher rates than other buffers. Inclusion of $10 \mathrm{mM}-\mathrm{NaCl}$ in these buffers did not change the rate of aspartate transport (measured at $60 \mu \mathrm{M}-\mathrm{L}$-aspartate).

Whereas aspartate uptake by intact bacteria increased slowly with concentration beyond $100 \mu \mathrm{M}$-aspartate, it levelled off at this concentration for membrane vesicle transport. These results indicated that the high affinity transport, observed in whole organisms and membrane vesicles, did not depend on the presence of $\mathrm{Na}^{+}$. The low affinity uptake of aspartate was observed only in whole organisms, and it showed a slightly higher rate in the presence of $\mathrm{Na}^{+}$. However, the 'initial' rate was determined from the uptake in the first 2 min and may contain a significant contribution from aspartate metabolism. No conclusions can, therefore, be drawn from these experiments about the mechanism by which sodium stimulates growth. This aspect will be analysed elsewhere. 


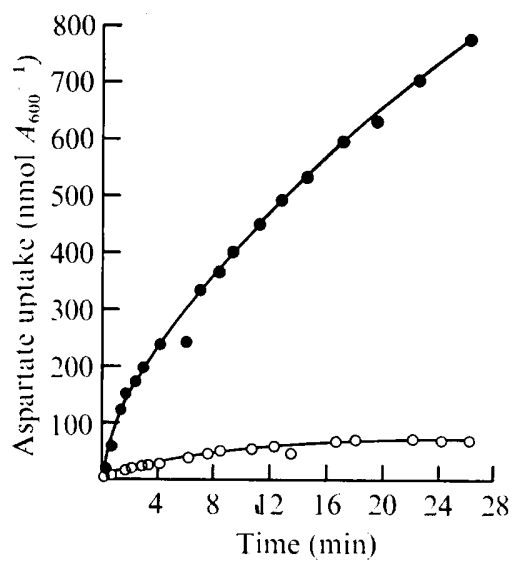

Fig. 6. Aspartate uptake at low and high concentrations. The aspH strain (61501) was grown to $A_{800}=0.5$ in $\mathrm{S} 6+\mathrm{Na}^{+}+25 \mathrm{~mm}$-glucose $(\mathrm{O})$ and in $\mathrm{S} 6+25 \mathrm{~mm}$-sodium aspartate $(\bullet)$. The organisms were then washed and resuspended in S6. Aspartate uptake was measured in $\mathbf{S} 6+\mathrm{Na}^{+}+$ $25 \mathrm{~mm}$-glucose $+100 \mu \mathrm{M}$-aspartate $(\mathrm{O})$ and in $\mathrm{S} 6+25 \mathrm{~mm}$-sodium aspartate $(\mathbf{O})$.

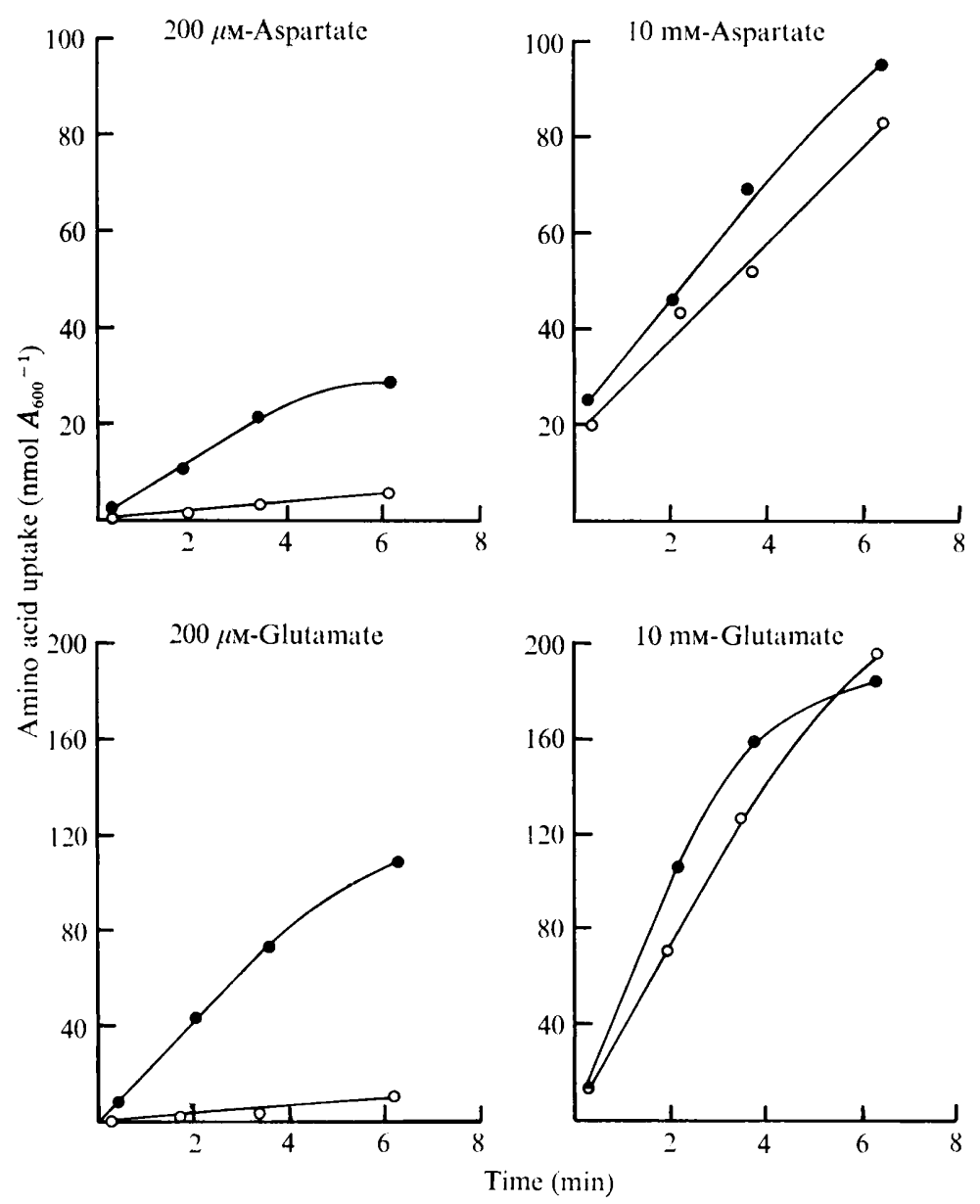

Fig. 7. Uptake of L-aspartate and L-glutamate at $200 \mu \mathrm{M}$ and $10 \mathrm{mM}$ by the aspH strain 61501 (๑) and the aspH aspT strain $61507(\bigcirc)$. Each strain was grown in $\$ 6+10 \mathrm{~mm}$-glycerol $+0.2 \%$ casein hydrolysate to $A_{600}=0.5$ and uptake was measured in the presence of $20 \mathrm{~mm}$-disodium glycerophosphate as described in Methods. 
Table 4. Initial rates of uptake of amino acids and keto acids by strains 60002 (trpC2) and 61507 (aspH1 aspT13 trpC2)

The bacteria were grown in $\mathrm{S} 6+10 \mathrm{~mm}$-glycerol $+0.2 \%$ casein hydrolysate to $A_{600}=0.5$, centrifuged and then uptake was measured in the presence of chloramphenicol $\left(50 \mu \mathrm{g} \mathrm{ml}^{-1}\right)$ and $20 \mathrm{~mm}$ disodium glycerophosphate as energy source. The uptake was initiated by the addition of ${ }^{14} \mathrm{C}$-labelled substrate to a final concentration of $0.2 \mathrm{~mm}$.

\begin{tabular}{|c|c|c|c|c|c|}
\hline \multirow[b]{2}{*}{ Substrate } & \multicolumn{2}{|c|}{$\begin{array}{l}\text { Initial rate of uptake } \\
\left(\text { nmol } A_{600}{ }^{-1} \mathrm{~min}^{-1}\right)\end{array}$} & \multirow[b]{2}{*}{ Substrate } & \multicolumn{2}{|c|}{$\begin{array}{l}\text { Initial rate of uptake } \\
\left(\mathrm{nmol} A_{600}^{-1} \mathrm{~min}^{-1}\right)\end{array}$} \\
\hline & 60002 & 61507 & & 60002 & 61507 \\
\hline Glycine & $6 \cdot 5$ & $5 \cdot 6$ & L-Histidine & $1 \cdot 1$ & $1 \cdot 2$ \\
\hline L-Alanine & $6 \cdot 6$ & $8 \cdot 5$ & L-Arginine & $1 \cdot 0$ & $1 \cdot 0$ \\
\hline L-Valine & $6 \cdot 1$ & $5 \cdot 1$ & L-Methionine & $1 \cdot 0$ & 0.9 \\
\hline L-Leucine & $6 \cdot 0$ & $5 \cdot 6$ & L-Proline & $1 \cdot 2$ & $8 \cdot 3$ \\
\hline L-Isoleucine & $3 \cdot 6$ & $4 \cdot 1$ & L- $\alpha$-Aminoisobutyrate & $4 \cdot 3$ & $4 \cdot 6$ \\
\hline L-Serine & $10 \cdot 8$ & $10 \cdot 8$ & DL-threo- $\beta$-Hydroxy- & $7 \cdot 9$ & 0.08 \\
\hline L-Threonine & $7 \cdot 2$ & $3 \cdot 8$ & aspartate & & \\
\hline L-Aspartate & $13 \cdot \overline{5}$ & 0.9 & L-Malate & $2 \cdot 7$ & $3 \cdot 0$ \\
\hline L-Asparagine & $17 \cdot 6$ & $15 \cdot 6$ & L-Succinate & $3 \cdot 2$ & $4 \cdot 0$ \\
\hline L-Glutamate & $25 \cdot 1$ & $1 \cdot 4$ & L-Fumarate & $3 \cdot 5$ & $3 \cdot 8$ \\
\hline L-Lysine & 0.9 & $1 \cdot 2$ & L-Pyruvate & 0.4 & $0 \cdot 3$ \\
\hline
\end{tabular}

\section{Properties of the low affinity transport system}

An $a s p H$ culture growing in $\mathrm{S} 6+25$ mM-sodium L-aspartate consumed aspartate at a rate of $33 \mathrm{nmol} A_{600}{ }^{-1} \mathrm{~min}^{-1}$ (measured after the initial high rate of aspartate uptake) (Fig. 6). This rate was about four times higher than the maximum rate $\left(8 \mathrm{nmol} A_{600}{ }^{-1} \mathrm{~min}^{-1}\right)$ of aspartate uptake in a culture growing in $\mathrm{S} 6+\mathrm{Na}^{+}+25 \mathrm{~mm}$-glucose, measured at $100 \mu \mathrm{M}-$ aspartate, the concentration at which the high affinity aspartate transport system was about saturated. Thus, aspartate can be taken up at a higher rate than would be possible by the high affinity transport system, but this uptake is effective only at very high aspartate concentrations, i.e. it has a low affinity $\left(K_{\mathrm{m}}\right)$ but a high velocity $\left(V_{\mathrm{max}}\right)$ for aspartate. The high rate may indicate the presence of a large number of transport molecules on the cell surface. The saturation of the aspartate transport in membrane vesicles above $100 \mu \mathrm{M}$ and the absence of transport in vesicles of aspT mutants indicates that the low affinity transport system is not energized by the proton motive force (except if these transport molecules are lost upon membrane vesicle isolation).

To measure the properties of the low affinity aspartate uptake system without any background of high affinity transport, a spontaneous double mutant aspH aspT13 (61507) was isolated on $\mathrm{S} 6+$ glucose plates containing $100 \mu \mathrm{M}$-THA. This double mutant was defective in the high affinity aspartate and glutamate transport (Fig. 7). With the ${ }^{14} \mathrm{C}$-labelled compounds at $200 \mu \mathrm{M}$, the uptake rates of aspartate and glutamate were distinctly lower than in the aspH strain. THA was also no longer taken up whereas the uptake of other amino and keto acids was not impaired (Table 4); compared to the standard strain (60002), the uptake of threonine was reduced by a factor of 2 and that of proline increased by a factor of 7 . This may be due to derepression resulting from the reduced amount of aspartate and glutamate taken up by the mutant bacteria or it may result from a secondary mutation. However, the uptake rates of $10 \mathrm{~mm}$-aspartate and glutamate were about the same in both strains (Fig. 7), i.e. the low affinity aspartate transport system was not impaired.

Conceivably, the aspartate uptake observed in the aspH aspT strain could result from an exchange with intracellular aspartate or some other compound (glutamate) that had accumulated in the organisms during prior growth. To exclude this possibility, the effect of inhibitors of the electron transport system and of uncouplers, i.e. compounds destroying the proton motive force, on the low affinity aspartate uptake was examined in the presence of 


\section{Table 5. Inhibition of the low affinity uptake of $\left[{ }^{14} \mathrm{C}\right]$ aspartic acid}

Strain 61507 (aspHI aspT13 trpC2) was grown in S6+10 mM-glycerol + 0.2\% casein hydrolysate to $A_{600}=0 \cdot 5$, centrifuged and resuspended in $\mathrm{S} 6$ containing inhibitor. Disodium glycerophosphate $(20 \mathrm{~mm})$ was added as energy source and the uptake was initiated by the addition of [14C]aspartate to a concentration of $5 \mathrm{~mm}$. Antimycin A, HOQNO, CCCP and valinomycin were dissolved in ethanol, dinitrophenol and amytal in dimethylsulphoxide (DMSO), and potassium azide in water. The final concentration of these solvents was less than $1 \%(v / v)$ and had no significant effect on aspartate uptake. The percentage inhibition is expressed relative to controls having the same ethanol or DMSO concentrations.

$\begin{array}{lcc}\text { Inhibitor* } & \text { Concn }(\mathrm{mM}) & \begin{array}{c}\text { Inhibition } \\ \text { of uptake }(\%)\end{array} \\ \text { Potassium azide } & 10.0 & 82.3 \\ \text { CCCP } & 0.01 & 95.5 \\ \text { Dinitrophenol } & 1.0 & 66.5 \\ \text { Antimycin A } & 0.5 & 45.7 \\ \text { HOQNO } & 0.05 & 87.9 \\ \text { Amytal } & 20.0 & 70.6 \\ \text { Valinomycin } & 0.1 & 80.9\end{array}$
oxide.

* CCCP, Carbonyl cyanide $m$-chlorophenylhydrazone; HOQNO, 2-Heptyl-4-hydroxyquinoline- $N$ -

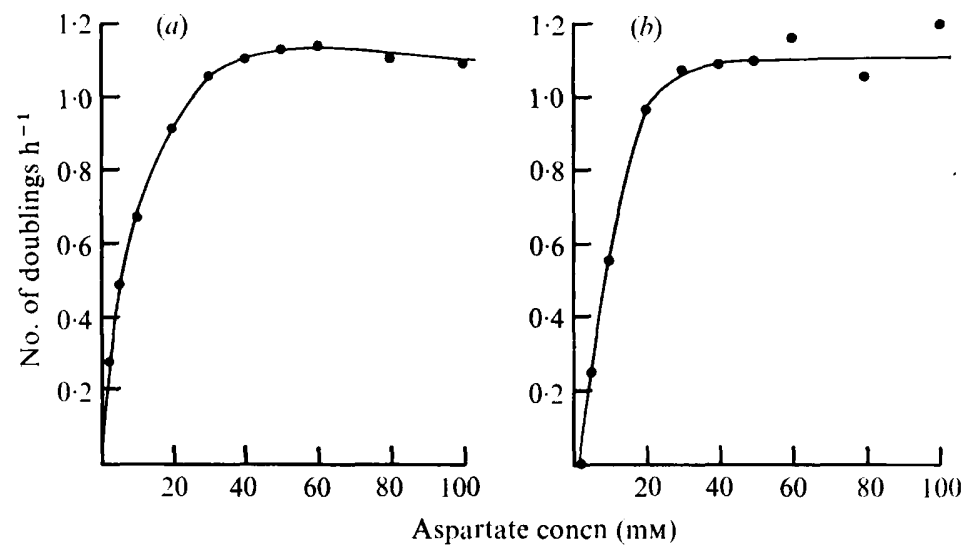

Fig. 8. Aspartate concentration dependence of growth of (a) the $a s p H$ strain 61501 and (b) the aspH aspT strain 61507. The bacteria were grown in S6 containing different concentrations of sodium L-aspartate.

glycerophosphate as energy source. Aspartate uptake was inhibited by all these compounds (Table 5), i.e. it depended on the cellular ability to metabolize and transport substrates. Consequently, the observed aspartate uptake did not result merely from an exchange with a previously accumulated intracellular compound. The observed high rate of aspartate uptake may depend on the immediate metabolism of the aspartate that has entered the organisms. The results do not exclude the possibility that aspartate transport requires the symport or antiport of some compound produced by or actively transported into the organisms.

The aspH aspT strain grew as well as the aspH strain (61501) in S6 containing high concentrations of sodium aspartate as sole carbon source (Fig. 8). Only at low aspartate concentrations $(<10 \mathrm{~mm}$ ), at which the contribution of the high affinity transport system to aspartate uptake becomes significant, was the growth rate of the aspH aspT strain significantly lower than that of the aspH strain. When $\left[{ }^{14} \mathrm{C}\right]$ aspartate was added to such a culture growing in $\mathrm{S} 6+25$ mm-sodium aspartate, the uptake of aspartate showed an initial rapid rate which changed to a slower constant rate after $2 \mathrm{~min}$. This constant rate of $25 \mathrm{nmol}$ 
$A_{600}{ }^{-1} \mathrm{~min}^{-1}$ reflects the rate at which aspartate was metabolized. Since this metabolism occurs rapidly due to the high aspartase activity and since the low affinity transport is active only at high extracellular aspartate concentrations (e.g. $25 \mathrm{mM}$ ), growth may not require active transport of aspartate into the cell. In fact, no active transport of aspartate was observed in membrane vesicles of the asp $T$ mutant. Facilitated transport may, therefore, suffice to provide aspartate at the necessary rate.

\section{REFERENCES}

Anagnostopoulos, C. \& Spizizen, J. (1961). Requirements for transformation in Bacillus subtilis. Journal of Bacteriology 81, 741-746.

Bisschop, A., Doddema, H. \& Konings, W. N. (1975). Dicarboxylic acid transport in membrane vesicles from Bacillus subtilis. Journal of Bacteriology 124, 613-622.

Fournier, R. E., McKillen, M. N., Pardee, A. B. \& WILLECKE, K. (1972). Transport of dicarboxylic acids in Bacillus subtilis: inducible uptake of Lmalate. Journal of Biological Chemistry 247, 5587-5595.

Hoch, J. A. \& Mathews, J. (1972). Genetic studies in Bacillus subtilis. In Spores $V$, pp. 113-116. Edited by H. O. Halvorson, R. Hanson and L. L. Campbell. Washington, D.C.: American Society for Microbiology.

Hoch, J. A., Barat, M. \& Anagnostopoulos, C. (1967). Transformation and transduction in recombination-defective mutants of Bacillus subtilis. Journal of Bacteriology 93, 1925-1937.

Iijima, T., Diesterhaft, M. D. \& Freese, E. (1977). Sodium effect of growth on aspartate and genetic analysis of a Bacillus subtilis mutant with high aspartase activity. Journal of Bacteriology 129, 1440-1447.

KABACK, H. R. (1971). Bacterial membranes. Methods in Enzymology XXII, 99-120.

Konings, W. N. \& Freese, E. (1972). Amino acid transport in membrane vesicles of Bacillus subtilis. Journal of Biological Chemistry 247, 2408-2418.
Konings, W. N., Bisschop, A., Veenhuis, M. \& Vermeulen, C. A. (1973). New procedure for the isolation of membrane vesicles of Bacillus subtilis and an electron microscopy study of their ultrastructure. Journal of Bacteriology 116, 14561465.

Kornguth, M. L. \& SAllach, H. J. (1960). $\beta$-Hydroxyaspartic acid: synthesis and separation of its diastereoisomers. Archives of Biochemistry and Biophysics 91, 39-42.

LeVIN, B. C. \& Freese, E. (1977). Comparison of the effects of two lipophilic acids, hexachlorophene and decanoate on Bacillus subtilis. Antimicrobial Agents and Chemotherapy 12, 357-367

OH, Y. K., Freese, E. B. \& FreEse, E. (1973). Abnormal septation and inhibition of sporulation by accumulation of $L-\alpha$-glycerophosphate in Bacillus subtilis mutants. Journal of Bacteriology 113, 1034-1045.

Michal, G. \& LANG, G. (1974). L-(-)-Glycerol-3phosphate. In Methods of Enzymatic Analysis, 2nd edn., vol. 3, pp. 1415-1418. Edited by H. U. Bergmeyer. New York and London: Academic Press.

Saito, H. \& MiURA, K. (1963). Preparation of transforming deoxyribonucleic acid by phenol treatment. Biochimica et biophysica acta 72, 619-629.

TAKAHASHI, I. (1966). Joint transfer of genetic markers in Bacillus subtilis. Journal of Bacteriology 91, 101-105. 